\title{
Cover crops change the phytosociology of weeds and the banana yield
}

\author{
Jorgiani Ávila1, Maria Gabriela Oliveira Andrade², Eduardo Pradi Vendruscolo ${ }^{3}$, Jordana \\ Dias Martins ${ }^{1}$, Sebastião Ferreira Lima ${ }^{1}$
}

${ }^{1}$ Universidade Federal de Mato Grosso do Sul, Campus de Chapadão do Sul, Chapadão do Sul, Mato Grosso do Sul, Brasil. E-mail: jorgianiavila@hotmail.com, jordana_dias_martins@hotmail.com, sebastiao.lima@ufms.br

${ }^{2}$ Universidade Estadual Paulista Júlio de Mesquita Filho, Campus de Ilha Solteira, Ilha Solteira, São Paulo, Brasil. E-mail: gabriela13andrade@hotmail.com

${ }^{3}$ Universidade Estadual de Mato Grosso do Sul, Unidade Universitária de Cassilândia, Cassilândia, Mato Grosso do Sul, Brasil.

E-mail: eduardopradi@gmail.com

Received: 07/02/2019; Accepted: 04/02/2020.

\section{ABSTRACT}

This work aimed to evaluate the phytosociology of weeds and the fruit yield of banana (cv. Tropical) in different soil coverings. The experimental design used was randomized blocks, with eight treatments and three replications. The treatments consisted of sowing of Canavalia ensiformis, Cajanus cajan, Crotalaria juncea, Stylosanthes 'Campo Grande', Crotalaria spectabilis, Sorghum bicolor, and Phaseolus lunatus between the rows of the banana trees. A control treatment was also used without cover crops. Weed phytosociology was evaluated in four treatments. The number of hands per bunch, the number of fruits per hand, the number of fruits per bunch, and the fruit yield were estimated in all treatments. In the phytosociological survey, 23 species were identified, in 13 families, especially Asteraceae and Poaceae families. Compared to the control, the coverage with $C$. cajan, $C$. juncea, and C. ensiformis provided a reduction in weed density of $108 \%, 71.7 \%$, and $14.6 \%$, respectively. C. ensiformis and $C$. cajan provided the highest yield of banana fruits, with an increase of $51.2 \%$ about the control. It is concluded that $C$. ensiformis and $C$. juncea provided the most significant suppression of weeds, while $C$. cajan and $C$. ensiformis provided the highest fruit yield.

Keywords: Musa sp, weed competition, vegetation cover, biological fixation, soil protection.

\section{Coberturas verdes alteram a fitossociologia de plantas daninhas e a produtividade de banana}

\section{RESUMO}

Com este trabalho, objetivou-se avaliar a fitossociologia de plantas daninhas e a produtividade de frutos de banana (cv. Tropical) em diferentes coberturas do solo. O delineamento experimental utilizado foi em blocos casualizados, com oito tratamentos e três repetições. Os tratamentos foram constituídos pelo plantio de Canavalia ensiformis, Cajanus cajan, Crotalaria juncea, Stylosanthes 'Campo Grande', Crotalaria spectabilis, Sorghum bicolor e Phaseolus lunatus na entrelinha das bananeiras. Também se utilizou um tratamento controle, sem o plantio de coberturas. Foi avaliada a fitossociologia das plantas daninhas em quatro tratamentos e o número de pencas por cacho, número de frutos por penca, número de frutos por cacho e produtividade de frutos em todos os tratamentos. No levantamento fitossociológico foram identificadas 23 espécies, em 13 famílias, destacando-se Asteraceae e Poaceae. Comparativamente ao controle, a cobertura com C. cajan, C. juncea e C. ensiformis proporcionaram uma redução na densidade de plantas daninhas de $108 \%, 71,7 \%$ e $14,6 \%$, respectivamente. C. ensiformis e C. cajan proporcionaram as maiores produtividades de frutos de banana, sendo observado incremento de $51,2 \%$ em relação ao controle. Conclui-se que as coberturas vegetais com C. ensiformis e $C$. juncea foram as que proporcionaram maior supressão de plantas daninhas, enquanto as coberturas vegetais com $C$. cajan e $C$. ensiformis proporcionaram a maior produtividade de frutos.

Palavras-chave: Musa sp., matocompetição, cobertura vegetal, fixação biológica, proteção do solo. 


\section{Introduction}

Inadequate weed management can cause significant losses in the production components of different species of economic interest, such as corn and crambe (Coelho et al., 2016; Lima et al., 2018), forest species (Eloy et al., 2014; Faria et al., 2018) and vegetables (Guerra et al., 2016; Vendruscolo et al., 2017), resulting in significant economic losses (Vicensi et al., 2011; Vendruscolo et al., 2017). Thus, for better control of interspecific competition between weeds and crops, herbicides are usually applied, which affects not only the weeds but the ecosystem (Myers et al., 2016; Van Bruggen et al., 2018).

The search for cultivation management that is less aggressive to the environment has culminated in the increase of studies on the use of biological methods for the control of insect pests, diseases, and weeds. For the weed control, the potential of some species to suppress the emergence of unwanted plants is observed, whether through shading, allelopathy, or even the formation of physical barriers (Moura Filho et al., 2015; Coelho et al., 2016).

Simultaneously with the suppression of weeds, the maintenance of cover plants allows the cycling of nutrients through the accumulation in phytomass, mineralization, and availability of these for crops of economic interest (Almeida and Câmara, 2011). In this sense, it appears that this technique, although studied and applied to annual crops, can also be used for fruit production, grown in a consortium between the planting rows (Paulino et al., 2010). Among the species used as cover crops, legumes stand out for having a higher capacity to release nutrients in the short term when compared to grass species due to the lower carbon: nitrogen ratio (Acosta et al., 2014).

Information obtained in scientific studies indicates benefits of using cover crops between the rows of established orchards, either by suppressing the development of weeds, maintaining edaphic quality or by making nutrients available (Partelli et al., 2010; Carvalho et al., 2013; Feitosa et al., 2009). For the banana crop (Musa sp.), positive results were also observed for the intercropped management of cover crops in the Brazilian semiarid region, improving the vegetative and reproductive development of plants (Quaresma et al., 2015), demonstrating their potential for employment in crops in other regions of the country. Therefore, it is essential to know about the species present in each cultivation system since interspecific interactions are observed (Coelho et al., 2016).

The work aimed to evaluate the effect of different cover crops on weed phytosociology and the fruit yield and production components of banana from BRS Tropical cultivar.

\section{Material and Methods}

The experiment was carried out in Chapadão do Sul - MS, at coordinates $18^{\circ} 46^{\prime} 17.8^{\prime \prime} \mathrm{S}, 52^{\circ} 37^{\prime} 27.7^{\prime \prime} \mathrm{W}$, and altitude of $813 \mathrm{~m}$. The soil in the area was classified as Latossolo Vermelho Distrófico of clayey texture, or Oxisol (Soil Survey Staff, 2014). The climate of the region is humid tropical (Aw), with a rainy season in summer and a dry season in winter, and an average annual rainfall of 1,850 $\mathrm{mm}$ (Cunha et al., 2013).

The banana plantation was implanted in 2014 and is composed of plants from BRS Tropical cultivar, with $2.5 \mathrm{~m}$ between rows and plants. The banana suckers were thinned at intervals of 45 to 60 days, avoiding their competition with the mother plant for water and nutrients. The elimination of male flower bud, which consists of the terminal portion of the rachis, when it reaches between 20 and $25 \mathrm{~cm}$ away from the last hand, was carried out to improve the health of the fruits through insect control. Fungicide, insecticide, and herbicide applications were carried out aiming at the control of diseases, insects, and excess of weeds outside the useful area of the experiment, to obtain good phytosanitary conditions in the banana plantation.

The experiment consisted of 200 plants, with 96 useful plants and the others serving as a border. Each experimental plot was formed by eight plants, and the four central plants were used as a useful plot. The treatments were distributed in three blocks, composed of eight treatments, totaling 24 plots. The treatments were formed by following cover crops Canavalia ensiformis, Cajanus cajan, Crotalaria juncea, Stylosanthes 'Campo Grande', Crotalaria spectabilis; Sorghum bicolor, Phaseolus lunatus L., and control treatment, without a cover crop.

The plots with cover crops were composed of $2.0 \mathrm{~m}$ wide and $3.0 \mathrm{~m}$ long. The area between the banana tree rows was desiccated using glyphosate $\left(1.0 \mathrm{~kg}\right.$ a.i. $\left.\mathrm{ha}^{-1}\right)+$ 2.4D $1.0\left(\mathrm{~kg} \mathrm{a.i}^{-1} \mathrm{ha}^{-1}\right)$ before the cover crops sowing. The sowing of the cover crops was performed manually in sowing furrows spaced $0.30 \mathrm{~m}$ apart.

Phytosociological assessments were performed with the square $(0.25 \mathrm{~m})$ randomly launched in each plot. The weeds present within that square were classified and separated between species. The data obtained were used to calculate the phytosociological indices defined by Mueller-Dombois and Ellenberg (1974):

a) Density (D): total number of individuals in a population/total number of species;

b) Relative Density (Dr): (species density $\mathrm{x}$ 100)/total species density;

c) Frequency $(\mathrm{F})$ : number of squares containing the species/total number of squares obtained (total area);

d) Relative frequency (Fr): (species frequency $\mathrm{x}$ 100)/total species frequency; 
e) Abundance (A): total number of individuals per species / total number of squares that contain the species;

f) Relative abundance (Ar): (species abundance $x$ 100)/total abundance of all species;

g) Importance Value Index (IVI): relative frequency + relative density + relative abundance (Curtis and Mcintosh, 1950; Mueller-Dombois and Ellemberg, 1974).

In the banana crop, after harvesting the bunches, the number of hands per cluster, the number of fruits per hand, the number of fruits per bunch, and the fruit yield $\left(\mathrm{Mg} \mathrm{ha}{ }^{-1}\right)$ were evaluated. Phytosociology data were organized in tables. The data of fruit production components and fruit yield were submitted to analysis of variance. The Tukey test compared the means at 5\% probability.

\section{Results and Discussion}

Only treatments with Canavalia ensiformis, Cajanus cajan, Crotalaria juncea, and the control was considered in the evaluation of phytosociology. The other cover crops had their emergence and initial establishment hindered by low germination resulting from a prolonged period without rain.

In the phytosociological survey, 23 weed species were identified in 13 families (Table 1). Asteraceae and Poaceae stood out, which participated with 6 and 4 species, $26.09 \%$ and $17.39 \%$, respectively. This result corroborates the data verified in the literature, which points out that, among the infesting families, Asteraceae and Poaceae stand out, being found in different areas of production, from grains to sugarcane (Oliveira and Freitas, 2008).

For the treatments evaluated between the rows of the banana trees, the treatment in which the highest density of weeds was obtained was the control treatment (Figure 1 ), which did not receive cover crops. This culminated in the absence of suppression, besides that carried out by the banana plants themselves. However, given that the banana plantation was fully established, the competition was not overly effective. It is observed that, for the banana crop, the first five months are limiting to development, requiring constant cleaning to avoid competition for resources (Carvalho and Vargas, 2008).

Table 1. List of weed species identified in the phytosociological survey carried out in the areas cultivated with the cover crops Canavalia ensiformis, Cajanus cajan, Crotalaria juncea, and control, distributed in family, scientific name and common name. Chapadão do Sul-MS. 2018.

\begin{tabular}{|c|c|c|}
\hline Scientific name & Family & Common name \\
\hline $\begin{array}{l}\text { Ageratum conyzoides } \\
\text { Bidens spp. } \\
\text { Conyza bonariensis } \\
\text { Conyza canadensis } \\
\text { Emilia fosbergii } \\
\text { Tridax procumbens }\end{array}$ & Asteraceae & $\begin{array}{l}\text { mentrasto, erva-de-são-joão, picão roxo } \\
\text { picão-preto, picão, pico-pico, piolho-de-padre } \\
\text { buva, voadeira, rabo-de-foguete } \\
\text { buva, voadeira, rabo-de-foguete } \\
\text { falsa serralha, algodão-de-preá, bela-emília } \\
\text { erva-de-touro, }\end{array}$ \\
\hline Alternanthera tenella & Amaranthaceae & apaga-fogo, carrapichinho, corrente, \\
\hline Cardamine bonariensis & Brassicaceae & agriãozinho-bravo, agriãozinho \\
\hline Commelina benghalensis & Commelinaceae & trapoeraba, rabo-de-cachorro, maria mole \\
\hline Ipomoea sp. & Convolvulaceae & corda-de-viola, corriola, campainha \\
\hline Cyperus rotundus & Cyperaceae & tiririca, tiririca-comum, junça, capim-dandá \\
\hline $\begin{array}{l}\text { Euphorbia heterophylla } \\
\text { Chamaesyce hirta }\end{array}$ & Euphorbiaceae & $\begin{array}{l}\text { leiteiro, amendoim-bravo, leiteira } \\
\text { erva-de-santa-luzia, burra-leiteira }\end{array}$ \\
\hline Senna sp. & Fabaceae & fedegoso \\
\hline Leonotis nepetifolia & Lamiaceae & cordão-de-frade, cordão-de-são-francisco \\
\hline Sida $s p$. & Malvaceae & guanxuma, mata-pasto, vassourinha \\
\hline $\begin{array}{l}\text { Cenchrus echinatus } \\
\text { Digitaria insularis } \\
\text { Eleusine indica } \\
\text { Panicum maximum }\end{array}$ & Poaceae & $\begin{array}{l}\text { capim-carrapicho, capim-amoroso, timbete } \\
\text { capim-amargoso, capim-colchão, capim-de- } \\
\text { capim-pé-de-galinha } \\
\text { capim colonião, capim-coloninho, capim- }\end{array}$ \\
\hline $\begin{array}{l}\text { Richardia brasiliensis } \\
\text { Spermacoce latifolia }\end{array}$ & Rubiaceae & $\begin{array}{l}\text { poaia, poaia-branca, poaia-do-campo } \\
\text { erva-quente, poaia-do-campo, erva-de-lagarto }\end{array}$ \\
\hline Solanum americanum & Solanaceae & maria-pretinha, erva-moura, caraxixá \\
\hline
\end{tabular}

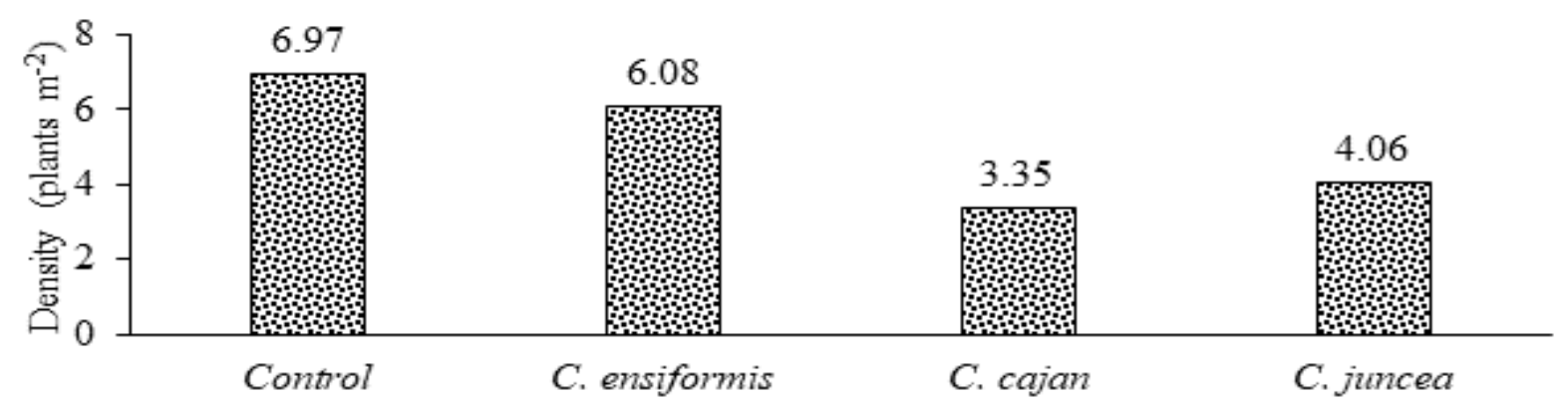

Figure 1. Weed density (plants $\mathrm{m}^{-2}$ ) found in the areas with cover crops evaluated. Chapadão do Sul-MS. 2018. 
Compared to the control treatment, weed density decreased when $C$. cajan, C. juncea, and C. ensiformis were implanted. In the plots containing these treatments, a reduction of $51.94 \%, 41.75 \%$, and $12.77 \%$ was observed in the weed density, respectively. These values indicate the potential of the cover crops to restrict the manifestation of the seed bank at the time of cultivation, being extremely important for the producer to take the necessary measures and make the appropriate choices. You should also consider other beneficial effects of the cover crops, such as nitrogen fixation.

The $C$. ensiformis is a recommended cover crop due to its rapid initial growth, and that it presents efficient control of invasive plants through suppression by shading, caused by the abundant presence of broad leaves, as observed by Coelho et al. (2016). Also, $C$. cajan, which has vigorous growth and tall plants, was the cover that most effectively suppressed the emergence of weeds, corroborating other studies in which its use as vegetation cover was adequate for the same purpose (Lima et al., 2014; Dantas et al., 2015).

The species Ageratum conyzoides stood out in the four treatments, presenting high IVI (Tables 2, 3, 4, and 5). The Commelina benghalensis species stood out in the treatment without cover crops, while the species Spermacoce latifolia, Richardia brasiliensis, and Alternanthera tenella stood out in the treatment with $C$. juncea. This shows that the suppression capacity is dependent on the weed species, the species used as cover, and the interaction between species.

Table 2. Number of the presence of squares (NS), number of individuals (NI), frequency (F), relative frequency (Fr), density (D), relative density (Dr), abundance (A), relative abundance (Ar) and importance value index (IVI) of weed species collected in area cultivated with from bananas without vegetation cover. Chapadão do Sul-MS. 2018.

\begin{tabular}{lccccccccc}
\hline Species & NS & NI & $\mathrm{F}$ & $\mathrm{Fr}(\%)$ & $\mathrm{D}$ & $\mathrm{Dr}(\%)$ & $\mathrm{A}$ & $\operatorname{Ar}(\%)$ & IVI \\
\hline Spermacoce latifolia & 15 & 290 & 0.09 & 9.57 & 1.747 & 25.06 & 19.33 & 16.81 & 51.45 \\
Tridax procumbens & 12 & 46 & 0.07 & 7.447 & 0.277 & 3.98 & 3.83 & 3.333 & 14.76 \\
Sida sp. & 10 & 85 & 0.06 & 6.383 & 0.512 & 7.35 & 8.5 & 7.703 & 21.43 \\
Ageratum conyzoides & 9 & 60 & 0.05 & 5.319 & 0.361 & 5.19 & 6.67 & 6.041 & 16.55 \\
Richardia brasiliensis & 14 & 177 & 0.08 & 8.511 & 1.066 & 15.3 & 12.6 & 10.99 & 34.8 \\
Cenchurus echinatus & 5 & 21 & 0.03 & 3.191 & 0.127 & 1.82 & 4.2 & 3.652 & 8.659 \\
Leonotis nepetifolia & 12 & 43 & 0.07 & 7.447 & 0.259 & 3.72 & 3.58 & 3.116 & 14.28 \\
Digitaria insularis & 11 & 64 & 0.06 & 6.383 & 0.386 & 5.53 & 5.82 & 5.059 & 16.97 \\
Eleusine indica & 12 & 79 & 0.07 & 7.447 & 0.476 & 6.83 & 6.58 & 5.725 & 20 \\
Emilia fosbergii & 11 & 35 & 0.06 & 6.383 & 0.211 & 3.03 & 3.18 & 2.767 & 12.17 \\
Bidens sp. & 7 & 17 & 0.04 & 4.255 & 0.102 & 1.47 & 2.43 & 2.112 & 7.836 \\
Chamaesyce hirta & 5 & 8 & 0.01 & 1.064 & 0.048 & 0.69 & 1.6 & 1.391 & 3.147 \\
Commelina benghalensis & 7 & 15 & 0.04 & 4.255 & 0.09 & 1.3 & 2.14 & 1.863 & 7.415 \\
Alternanthera tenella & 11 & 148 & 0.06 & 6.383 & 0.892 & 12.8 & 13.5 & 11.7 & 30.87 \\
Sonchus oleraceus & 6 & 10 & 0.04 & 3.83 & 0.06 & 0.86 & 1.67 & 1.449 & 6.143 \\
Euphorbia heterophylla & 7 & 26 & 0.04 & 4.255 & 0.157 & 2.25 & 3.71 & 3.23 & 9.732 \\
Panicum maximum & 2 & 11 & 0.01 & 1.277 & 0.066 & 0.95 & 5.5 & 4.783 & 7.01 \\
Ipomoea sp. & 3 & 3 & 0.02 & 1.915 & 0.018 & 0.26 & 1 & 0.87 & 3.044 \\
Conyza sp. & 4 & 12 & 0.02 & 2.553 & 0.072 & 1.04 & 3 & 2.609 & 6.199 \\
Portulaca oleracea & 2 & 3 & 0.01 & 1.064 & 0.018 & 0.26 & 1.5 & 1.304 & 2.627 \\
\hline Total & 166 & 1158 & 0.94 & 99.57 & 6.97 & 100 & 110 & 96.51 & 295.1 \\
\hline
\end{tabular}

Table 3. Number of the presence of squares (NS), number of individuals (NI), frequency (F), relative frequency (Fr), density (D), relative density (Dr), abundance (A), relative abundance (Ar) and importance value index (IVI) of weed species collected in area cultivated with bananas and with vegetation cover of Canavalia ensiformis. Chapadão do Sul-MS. 2018.

\begin{tabular}{|c|c|c|c|c|c|c|c|c|c|}
\hline Species & NQ & $\mathrm{NI}$ & $\mathrm{F}$ & $\operatorname{Fr}(\%)$ & $\mathrm{D}$ & $\operatorname{Dr}(\%)$ & $\mathrm{A}$ & $\operatorname{Ar}(\%)$ & IVI \\
\hline Spermacoce latifolia & 19 & 403 & 0.123 & 0.079 & 2.6 & 42.76316 & 21.2 & 27.46 & 70.31 \\
\hline Tridax procumbens & 2 & 3 & 0.013 & 0.008 & 0.02 & 0.318336 & 1.5 & 1.942 & 2.269 \\
\hline Sida sp. & 6 & 17 & 0.039 & 0.025 & 0.11 & 1.803905 & 2.83 & 3.669 & 5.498 \\
\hline Ageratum conyzoides & 15 & 233 & 0.097 & 0.062 & 1.5 & 24.72411 & 15.5 & 20.11 & 44.9 \\
\hline Richardia brasiliensis & 12 & 56 & 0.077 & 0.05 & 0.36 & 5.942275 & 4.67 & 6.043 & 12.03 \\
\hline Cenchurus echinatus & 6 & 7 & 0.039 & 0.025 & 0.05 & 0.742784 & 1.17 & 1.511 & 2.278 \\
\hline Leonotis nepetifolia & 5 & 8 & 0.032 & 0.021 & 0.05 & 0.848896 & 1.6 & 2.072 & 2.941 \\
\hline Digitaria insularis & 14 & 62 & 0.09 & 0.058 & 0.4 & 6.578947 & 4.43 & 5.734 & 12.37 \\
\hline Eleusine indica & 4 & 10 & 0.026 & 0.017 & 0.06 & 1.061121 & 2.5 & 3.237 & 4.315 \\
\hline Emilia fosbergii & 6 & 26 & 0.039 & 0.025 & 0.17 & 2.758913 & 4.33 & 5.611 & 8.395 \\
\hline Bidens sp. & 21 & 21 & 0.135 & 0.087 & 0.14 & 2.228353 & 1 & 1.295 & 3.611 \\
\hline Chamaesyce hirta & 6 & 14 & 0.039 & 0.025 & 0.09 & 1.485569 & 2.33 & 3.021 & 4.532 \\
\hline Commelina benghalensis & 15 & 44 & 0.097 & 0.062 & 0.28 & 4.66893 & 2.93 & 3.798 & 8.53 \\
\hline Alternanthera tenella & 4 & 9 & 0.026 & 0.017 & 0.06 & 0.955008 & 2.25 & 2.913 & 3.885 \\
\hline Sonchus oleraceus & 9 & 13 & 0.058 & 0.037 & 0.08 & 1.379457 & 1.44 & 1.87 & 3.287 \\
\hline Euphorbia heterophylla & 4 & 4 & 0.026 & 0.017 & 0.03 & 0.424448 & 1 & 1.295 & 1.736 \\
\hline Panicum maximum & 2 & 5 & 0.013 & 0.008 & 0.03 & 0.53056 & 2.5 & 3.237 & 3.776 \\
\hline Ipomoea sp. & 2 & 2 & 0.013 & 0.008 & 0.01 & 0.212224 & 1 & 1.295 & 1.515 \\
\hline Conyza sp. & 1 & 1 & 0.006 & 0.004 & 0.01 & 0.106112 & 1 & 1.295 & 1.405 \\
\hline Portulaca oleracea & 2 & 4 & 0.013 & 0.008 & 0.03 & 0.424448 & 2 & 2.59 & 3.022 \\
\hline Total & 155 & 942 & 1 & 0.645 & 6.08 & 99.95 & 77.2 & 100 & 200.6 \\
\hline
\end{tabular}


Table 4. Number of the presence of squares (NS), number of individuals (NI), frequency (F), relative frequency (Fr), density (D), relative density (Dr), abundance (A), relative abundance (Ar) and importance value index (IVI) of weed species collected in area cultivated with bananas and with vegetation cover of Cajanus cajan. Chapadão do Sul-MS. 2018.

\begin{tabular}{lccccccccc}
\hline Species & $\mathrm{NQ}$ & $\mathrm{NI}$ & $\mathrm{F}$ & $\mathrm{Fr}(\%)$ & $\mathrm{D}$ & $\mathrm{Dr}(\%)$ & $\mathrm{A}$ & $\mathrm{Ar}(\%)$ & $\mathrm{IVI}$ \\
\hline Spermacoce latifolia & 9 & 85 & 0.07 & 7.14 & 0.67 & 16.6 & 9.444 & 15.36 & 39.12 \\
Tridax procumbens & 1 & 1 & 0.01 & 0.79 & 0.01 & 0.2 & 1 & 1.626 & 2.615 \\
Sida sp. & 7 & 56 & 0.06 & 5.56 & 0.44 & 10.9 & 8 & 13.01 & 29.51 \\
Ageratum conyzoides & 13 & 81 & 0.1 & 10.3 & 0.64 & 15.8 & 6.231 & 10.13 & 36.28 \\
Richardia brasiliensis & 12 & 66 & 0.1 & 9.52 & 0.52 & 12.9 & 5.5 & 8.945 & 31.37 \\
Cenchurus echinatus & 3 & 4 & 0.02 & 2.38 & 0.03 & 0.78 & 1.333 & 2.168 & 5.331 \\
Leonotis nepetifolia & 4 & 12 & 0.03 & 3.17 & 0.1 & 2.35 & 3 & 4.879 & 10.4 \\
Digitaria insularis & 16 & 80 & 0.13 & 12.7 & 0.63 & 15.6 & 5 & 8.131 & 36.47 \\
Eleusine indica & 3 & 3 & 0.02 & 2.38 & 0.02 & 0.59 & 1 & 1.626 & 4.594 \\
Emilia fosbergii & 10 & 17 & 0.08 & 7.94 & 0.13 & 3.32 & 1.7 & 2.765 & 14.02 \\
Bidens sp. & 11 & 37 & 0.09 & 8.73 & 0.29 & 7.23 & 3.364 & 5.47 & 21.43 \\
Chamaesyce hirta & 17 & 36 & 0.13 & 13.5 & 0.29 & 7.04 & 2.118 & 3.444 & 23.97 \\
Commelina benghalensis & 1 & 1 & 0.01 & 0.79 & 0.01 & 0.2 & 1 & 1.626 & 2.615 \\
Alternanthera tenella & 2 & 2 & 0.02 & 1.59 & 0.02 & 0.39 & 1 & 1.626 & 3.605 \\
Sonchus oleraceus & 4 & 6 & 0.03 & 3.17 & 0.05 & 1.17 & 1.5 & 2.439 & 6.787 \\
Euphorbia heterophylla & 1 & 2 & 0.01 & 0.79 & 0.02 & 0.39 & 2 & 3.253 & 4.437 \\
Panicum maximum & 5 & 9 & 0.04 & 3.97 & 0.07 & 1.76 & 1.8 & 2.927 & 8.655 \\
Ipomoea sp. & 4 & 10 & 0.03 & 3.17 & 0.08 & 1.95 & 2.5 & 4.066 & 9.195 \\
Conyza sp. & 1 & 1 & 0.01 & 0.79 & 0.01 & 0.2 & 1 & 1.626 & 2.615 \\
Solonum americanum & 1 & 1 & 0.01 & 0.79 & 0.01 & 0.2 & 1 & 1.626 & 2.615 \\
Cardamine bonariensis & 1 & 2 & 0.01 & 0.79 & 0.02 & 0.39 & 2 & 3.253 & 4.437 \\
\hline Total & 126 & 512 & 1 & 100 & 4.06 & 100 & 61.49 & 99.99 & 300.1 \\
\hline
\end{tabular}

Table 5. Number of the presence of squares (NS), number of individuals (NI), frequency (F), relative frequency (Fr), density (D), relative density (Dr), abundance (A), relative abundance (Ar) and importance value index (IVI) of weed species collected in area cultivated with bananas and with vegetation cover of Crotalária juncea. Chapadão do Sul-MS. 2018.

\begin{tabular}{lccccccccc}
\hline Species & $\mathrm{NQ}$ & $\mathrm{NI}$ & $\mathrm{F}$ & $\mathrm{Fr}(\%)$ & $\mathrm{D}$ & $\mathrm{Dr}(\%)$ & $\mathrm{A}$ & $\operatorname{Ar}(\%)$ & $\mathrm{IVI}$ \\
\hline Spermacoce latifolia & 15 & 118 & 0.08 & 8.152 & 0.641 & 19.1 & 7.87 & 12.2 & 39.49 \\
Tridax procumbens & 8 & 30 & 0.04 & 4.348 & 0.163 & 4.87 & 3.75 & 5.814 & 15.03 \\
Sida sp. & 10 & 31 & 0.05 & 5.435 & 0.168 & 5.03 & 3.1 & 4.806 & 15.27 \\
Ageratum conyzoides & 8 & 38 & 0.04 & 4.348 & 0.207 & 6.16 & 4.75 & 7.364 & 17.88 \\
Richardia brasiliensis & 11 & 36 & 0.06 & 5.978 & 0.196 & 5.84 & 3.27 & 5.074 & 16.89 \\
Cenchurus echinatus & 7 & 14 & 0.04 & 3.804 & 0.076 & 2.27 & 2 & 3.101 & 9.176 \\
Leonotis nepetifolia & 7 & 12 & 0.04 & 3.804 & 0.065 & 1.95 & 1.71 & 2.658 & 8.409 \\
Digitaria insularis & 12 & 22 & 0.07 & 6.522 & 0.12 & 3.57 & 1.83 & 2.842 & 12.93 \\
Eleusine indica & 12 & 27 & 0.07 & 6.522 & 0.147 & 4.38 & 2.25 & 3.488 & 14.39 \\
Emilia fosbergii & 12 & 38 & 0.07 & 6.522 & 0.207 & 6.16 & 3.17 & 4.91 & 17.6 \\
Bidens sp. & 8 & 34 & 0.04 & 4.348 & 0.185 & 5.52 & 4.25 & 6.589 & 16.45 \\
Chamaesyce hirta & 9 & 26 & 0.05 & 4.891 & 0.141 & 4.22 & 2.89 & 4.479 & 13.59 \\
Commelina benghalensis & 8 & 27 & 0.04 & 4.348 & 0.147 & 4.38 & 3.38 & 5.233 & 13.96 \\
Alternanthera tenella & 13 & 65 & 0.07 & 7.065 & 0.353 & 10.5 & 5 & 7.752 & 25.36 \\
Sonchus oleraceus & 7 & 12 & 0.04 & 3.804 & 0.065 & 1.95 & 1.71 & 2.658 & 8.409 \\
Euphorbia heterophylla & 13 & 25 & 0.07 & 7.065 & 0.136 & 4.06 & 1.92 & 2.982 & 14.1 \\
Panicum maximum & 7 & 13 & 0.04 & 3.804 & 0.071 & 2.11 & 1.86 & 2.879 & 8.793 \\
Ipomoea sp. & 5 & 5 & 0.03 & 2.717 & 0.027 & 0.81 & 1 & 1.55 & 5.079 \\
Conyza sp. & 2 & 5 & 0.01 & 1.087 & 0.027 & 0.81 & 2.5 & 3.876 & 5.774 \\
Solonum americanum & 6 & 26 & 0.03 & 3.261 & 0.141 & 4.22 & 4.33 & 6.718 & 14.2 \\
Cardamine bonariensis & 3 & 12 & 0.02 & 1.63 & 0.065 & 1.95 & 4 & 6.202 & 9.779 \\
\hline Total & 184 & 618 & 1 & 100 & 3.35 & 100 & 64.5 & 106.3 & 306.5 \\
\hline
\end{tabular}

A possible technique to aid suppression would be to use cover crop species together, since weeds behave differently, depending on the species used as a cover crop. The higher production of dry mass by area, observed with the use of cover crops cocktails, culminates in a significant stifling of weeds, in addition to increasing the yield of plants of economic interest such as corn (Coelho et al., 2016). About the variables related to the banana crop, it was found that for the number of hands per bunch and the number of fruits per bunch, the treatments composed by the species $C$. ensiformis, C. juncea, C. spectablis, C. cajan, and $P$. lunatus were significantly superior to the control treatment. For the number of fruits per hand, only the treatment with $C$. ensiformis was significantly superior to the control treatment. The yield was benefited using all cover species, except for Sorghum bicolor and $P$. lunatus (Table 6). 
Table 6. Hands per bunch, fruits per hand, fruits per bunch, and yield of banana cultivar Tropical grown in an area with different cover crops. Chapadão do Sul-MS. 2018.

\begin{tabular}{lcccc}
\hline Treatments & Hands per bunch & Fruits per hand & Fruits per bunch & ${\text { Yield }\left(\mathrm{Mg} . \mathrm{ha}^{-1}\right)}^{\text {Control }}$ \\
Sorghum bicolor & $7.20 \mathrm{c}$ & $15.43 \mathrm{bcd}$ & $111.08 \mathrm{c}$ & $16.80 \mathrm{~d}$ \\
Stylosantes & $7.83 \mathrm{bc}$ & $15.71 \mathrm{abcd}$ & $123.02 \mathrm{bc}$ & $20.0 \mathrm{bcd}$ \\
P. lunatus & $7.83 \mathrm{bc}$ & $14.70 \mathrm{~d}$ & $115.15 \mathrm{c}$ & $21.40 \mathrm{~b}$ \\
C. cajan & $8.16 \mathrm{ab}$ & $16.44 \mathrm{ab}$ & $134.14 \mathrm{ab}$ & $17.30 \mathrm{~cd}$ \\
C. spectablis & $8.57 \mathrm{ab}$ & $15.94 \mathrm{abc}$ & $136.63 \mathrm{ab}$ & $25.50 \mathrm{a}$ \\
C. juncea & $8.70 \mathrm{a}$ & $15.33 \mathrm{bcd}$ & $133.41 \mathrm{ab}$ & $20.40 \mathrm{bc}$ \\
C. ensiformis & $8.80 \mathrm{a}$ & $15.21 \mathrm{~cd}$ & $133.84 \mathrm{ab}$ & $22.80 \mathrm{ab}$ \\
\hline
\end{tabular}

Averages followed by the same letter in the column do not differ statistically from each other by Tukey test at 5\% probability level.

Specifically, for yield, it was observed that the treatments composed by $C$. ensiformis and $C$. cajan stood out from the others, not differing significantly from the treatment composed by $C$. juncea (Table 6). These treatments provided increments of $50.60 \%$, $51.79 \%$, and $35.71 \%$, respectively. Parts of these benefits result from the capacity of these plants to perform biological nitrogen fixation and nutrient release after decomposition (Almeida and Câmara, 2011), combined with the good soil cover which they provide, which results in direct interference in the emergence of weeds (Moura Filho et al., 2015; Coelho et al., 2016).

Most of the infesting species have fast germination, short cycle, high production of diaspores, and a high degree of interference, becoming extremely aggressive in competition with cultivated plants. This dynamic capacity of weeds makes the management of the productive system more complex, requiring management actions to reduce the immediate number of weeds capable of competing with the crop. This whole process makes the system more costly (Vendruscolo et al., 2017), in addition to harming the environment more intensely, which can even lead to contamination of the marketed products and the degradation of the soil and water present in the environment (Myers et al., 2016; Van Bruggen et al., 2018).

In this way, given the results obtained, the possibility of using cover crops as a technique to minimize weed infestation is verified, allowing the lesser introduction of herbicides into the production system. Additionally, the maintenance of the cover crops will provide better maintenance of the edaphic conditions, improving the development of the plants.

\section{Conclusions}

The presence of cover crops provides suppression of weeds in an established banana plantation.

C. cajan and $C$. ensiformis, used as a cover crop between the banana rows, increase the components of production and fruit yield.

\section{Bibliographic References}

Acosta, I.J.A., Amado, T.J.C., Silva, L.S., Santi, A., Weber, M.A., 2014. Decomposição da fitomassa de plantas de cobertura e liberação de nitrogênio em função da quantidade de resíduos aportada ao solo sob sistema plantio direto. Ciência Rural, 44(5), 1-9.

Almeida, K.D., Câmara, F.L.A., 2011. Produtividade de biomassa e acúmulo de nutrientes em adubos verdes de verão, em cultivos solteiros e consorciados. Revista Brasileira de Agroecologia, 6(2), 55-62.

Carvalho, J.E.B., Vargas, L., 2008. Manejo e controle de plantas infestantes em frutíferas, in: Vargas, L., Roman, E.S. (Ed.), Manual de manejo e controle de plantas daninhas. Embrapa Trigo, Passo Fundo, p. 561-601.

Carvalho, W.P., Carvalho, G.J., Neto, D.D.O.A., Teixeira, L.G.V., 2013. Desempenho agronômico de plantas de cobertura usadas na proteção do solo no período de pousio. Pesquisa Agropecuária Brasileira, 48(2), 157-166.

Coelho, S.P., Galvão, J.C.C., Campos, S.A., Trogello, E., Pereira, L.P.L., Barrella, T.P., Cecon, P.R., Pereira, A.J., 2016. Coberturas vegetais na supressão de plantas daninhas em sistema de plantio direto orgânico de milho. Revista Brasileira de Milho e Sorgo, 15(1), 65-72.

Cunha, F.F., Magalhães, F.F., Castro, M.A., 2013. Métodos para estimativa da evapotranspiração de referência para Chapadão do Sul-MS. Revista Engenharia na Agricultura, 21(2), 159-172.

Curtis, J.T., Mcintosh, R.P., 1950. The interrelations of certain analytic and synthetic phytosociological characters. Ecology, 31(3), 434-455.

Dantas, R.A., Carmona, R., Carvalho, A.M., Rein, T.A., Malaquias, J.V., Santos, J.D.D.G., 2015. Produção de matéria seca e controle de plantas daninhas por leguminosas consorciadas com cana-de-açúcar em cultivo orgânico. Pesquisa Agropecuária Brasileira, 50(8), 681-689.

Eloy, E., Caron, B.O., Trevisan, R., Monteiro, G.C., Elli, E.F., 2014. Período adequado de controle de plantas invasoras em plantios florestais. Revista Ciência da Madeira, 5(2), 80-84.

Faria, J.T., Gonçalves, E.O., Delarmelina, W.M., Assumpção, C.M., Caldeira, M.W., 2018. Influência da mato-competição de capim-braquiária no crescimento inicial de espécies florestais em plantio misto. Revista de Ciências Agroambientais, 16(1), 62-71. 
Feitosa, H.O., Gonçalves, F.M., Carvalho, C.M., Guerra, J.G.M., 2009. Influência da adubação orgânica e da cobertura viva em figueira com irrigação suplementar. Revista Brasileira de Agricultura Irrigada-RBAI, 3(2), 88-94.

Lima, S.F., Timossi, P.C., Almeida, D.P., Silva, U.R., 2014. Fitossociologia de plantas daninhas em convivência com plantas de cobertura. Revista Caatinga, 27(2), 37-47.

Lima, S.F., Timossi, P.C., Brod, E., Teixeira, I.R., Silva, J.A., 2018. Matocompetição na cultura de Crambe abyssinica cultivado em safra e safrinha. Cultura Agronômica: Revista de Ciências Agronômicas, 27(3), 297-311.

Moura Filho, E.R., Macedo, L.P.M., Silva, A.R.S., 2015. Levantamento fitossociológico de plantas daninhas em cultivo de banana irrigada. Holos, 2(1), 92-97.

Mueller-Dombois, D., Ellenberg, H., 1974. Aims and methods of vegetation ecology. John Wiley and Sons, New York.

Myers, J.P., Antoniou, M.N., Blumberg, B., Carroll, L., Colborn, T., Everett, L.G., Hansen, M., Landrigan, P.J., Lanphear, B.P., Mesnage, R., Vandenberg, L.N., Saal, F.S., Welshons, W.V., Benbrook, C.M., 2016. Concerns over use of glyphosate-based herbicides and risks associated with exposures: a consensus statement. Environmental Health, $15(1), 1-13$.

Oliveira, A.R., Freitas, S.P., 2008. Levantamento fitossociológico de plantas daninhas em áreas de produção de cana-de-açúcar. Planta Daninha, 26(1), 33-46.

Partelli, F.L., Vieira, H.D., Freitas, S.P., Espindola, J.A.A., 2010. Aspectos fitossociológicos e manejo de plantas espontâneas utilizando espécies de cobertura em cafeeiro Conilon orgânico. Semina: Ciências Agrárias, 31(3), 605-617.
Paulino, G.M., Alves, B.J.R., Barroso, D.G., Urquiaga, S., Espindola, J.A.A., 2010. Fixação biológica e transferência de nitrogênio por leguminosas em pomar orgânico de mangueira e gravioleira. Pesquisa Agropecuária Brasileira, 44(12), 15981607.

Quaresma, M.A.L., Oliveira, F.L., Silva, D.M.N., Coelho, R.I., Costa, E.C., 2015. Desempenho de bananeiras cultivar "nanicão" sobre cobertura viva de solo no semiárido. Revista Caatinga, 28(4), 110-115.

Soil Survey Staff, 2014. Keys to Soil Taxonomy, twelfth ed. USDA-Natural Resources Conservation Service, Washington, DC.

Van Bruggen, A.H.C., He, M.M., Shin, K., Mai, V., Jeong, K.C., Finckh, M.R., Morris, J.G., 2018. Environmental and health effects of the herbicide glyphosate. Science of The Total Environment, 616-617, 255-268.

Vendruscolo, E.P., Campos, L.F.C., Arruda, E.M., Seleguini, A., 2017. Análise econômica da produção de alface crespa em cultivo sucessivo de plantas de cobertura em sistema de plantio direto. Revista Brasileira de Ciências Agrárias, 12(4), 458-463.

Vicensi, M.M., Araújo, E.O., Kikuti, H., Camacho, M.A., 2011. Manejo do solo e adubação nitrogenada na supressão de plantas daninhas na cultura do feijão de inverno irrigado. Revista Ciência Agronômica, 42(3), 758-764. 